\title{
Application of Geoinformatics in Ground Water Augmentation of AAM Water Shed
}

\author{
${ }^{* 1}$ Harshad D Bhave, ${ }^{2}$ Kameshwar Rao Tallapragada, ${ }^{3}$ Manoj S Tiwari \\ ${ }^{1,2,3}$ Shri Ramdeobaba College of Engineering and Management, Nagpur \\ Email:havehd@rknec.edu,raotk@rknec.edu, tiwarims@rknec.edu
}

Received: 07th November 2019, Accepted: 31st January 2020, Published: 29th February 2020

\begin{abstract}
Groundwater is considered as the preferred source of water for meeting domestic, industrial and agricultural requirements, due to its longer residence time in the ground, low level of contamination, wide distribution, and availability within the reach of the end user. Even the existing wells are getting dried-up due to depletion of ground water table as the natural recharge is not sufficient. Groundwater recharge is a basic pre-requisite for efficient groundwater resource development and management, which is particularly vital for India with widely prevalent semi-arid and arid climate. In case the natural recharge is not sufficient, it has to be met through artificial recharge. To provide artificial recharge structures and to construct them, appropriate locations are selected. Scientifically, each hydro- geomorphic unit will be evaluated for its recharge potential and suitably a map showing such groundwater recharge potential zones for appropriate recharge would be prepared. Using remote sensing and geographic information system (GIS) a number of different thematic maps of the same area are prepared and overlaid them to form a new integrated layer. This study was aimed to identify the groundwater recharge potential zones, to be used for better and improved groundwater resources. The thematic layers considered in this study are geomorphology, soil, land use land cover, slope (\%) which is prepared using satellite imagery and other conventional data. The thematic layers were first digitized from satellite imagery, supported by ancillary data such as toposheets and field investigation data, finally all thematic layers were digitized on Arc-GIS software to identify the groundwater recharge potential zones for the study area to generate a map and recharging methods were suggested.
\end{abstract}

Keywords

Ground Water, Recharge, Potential Zones, Satellite Imagery, Geomorphology

\section{Introduction}

Groundwater recharge refers to the entry of water from the unsaturated zone below the water table surface, together with the associated flow from the water table within the saturated zone. Groundwater recharge occurs when water flows past the groundwater level and infiltrates into the saturated zone. Field investigations help to explain the process of groundwater recharge and evaluate the spatial-temporal difference in the study area. However, these field investigations often focus on a single affecting factor or an indirect site-specific detail for groundwater recharge, reducing the reliability of the investigations. In recent times remote sensing and geographic information system technique is proved to be a cost effective and time saving tool to produce valuable data on geomorphology, geology, land use land cover, slope, lineament, lithology, etc., which also helps to decipher groundwater recharge potential zones. Many researchers such as Chaudhary et al. (1996), Rajat C. Mishra et al. (2010), and Jyoti Sarup et al. (2011) have used the approach of remote sensing and GIS for identification of groundwater potential zones and exploration of groundwater in locating the artificial recharge sites[5][8][10]. Akram Javed et al. (2009), Narendra et al. (2013) have used remote sensing and GIS techniques for delineation of groundwater potential zones[7][9]. Jothiprakash V. et al. (2003), Balachandar D. et al. (2010), Binay Kumar et al. (2011), Nepal C. Mondal et al. (2011) have used the remote sensing and GIS technique for generation of groundwater recharge zones map for the improvement and development of groundwater regions[1][2][11]. Subagunasekar M. et al. (2012) have applied GIS for assessment of the groundwater recharge potential zones. J. Brema et al. (2012) have used GIS for identification of sites suitable for artificial recharging and groundwater flow modelling[3][12]. Integrated approach of remote sensing and GIS can provide in decision making of mapping, planning of groundwater resources and management of groundwater resources for its efficient and cost effective use for a region or state.

In this research, the study area of AAM watershed is divided into mini and micro sheds using GIS software. The ground water recharge and suitability of various artificial ground water recharge techniques were studied on basis of different geological parameters like geomorphology, land use land cover, slope and soil[4][6]. According to these geological parameters different zones of AAM watershed were divided and studied in detail. On the basis of these parameters correlation between the suitability of artificial recharge techniques and properties of different zones of AAM watershed was made by assigning specific method to different watersheds. Then the discharge of different watersheds was calculated. Actual discharge available for 
artificial recharge was calculated using rational method after considering the losses.

\section{Study Area}

The study area admeasuring 335.6sq. km is AAM River, which is a tributary of Wainganga catchment of Godavari basin which is located at Umrer tehsil in Nagpur district of Maharashtra. It extends with latitudes of $20^{\circ} 54^{\prime} 6.698^{\prime \prime} \mathrm{N}$ to $21^{\circ} 0$ ' $0 " \mathrm{~N}$ and longitudes of $79^{\circ} 10^{\prime} 20^{\prime \prime} \mathrm{E}$ to $79^{\circ} 39^{\prime} 05^{\prime \prime} \mathrm{E}$, which lies in Survey of India toposheet bearing numbers $55 \mathrm{P} / 1,55 \mathrm{P} / 5$. This site was chosen because the depletion of water level depth and fall in long term trend of rainfall data. Hence the groundwater recharging methodology is suggested.

The study area is divided into three parts WGA-2A, WGA-3A andWGA-4A. 5 mini-watersheds and 48 micro-watersheds depending on the drainage characteristics with the slope, contour value and drainage flow. The mini, micro watershed and Geomorphological maps are shown in the Figure 1. The process of dividing was done with help of ARC-GIS software.
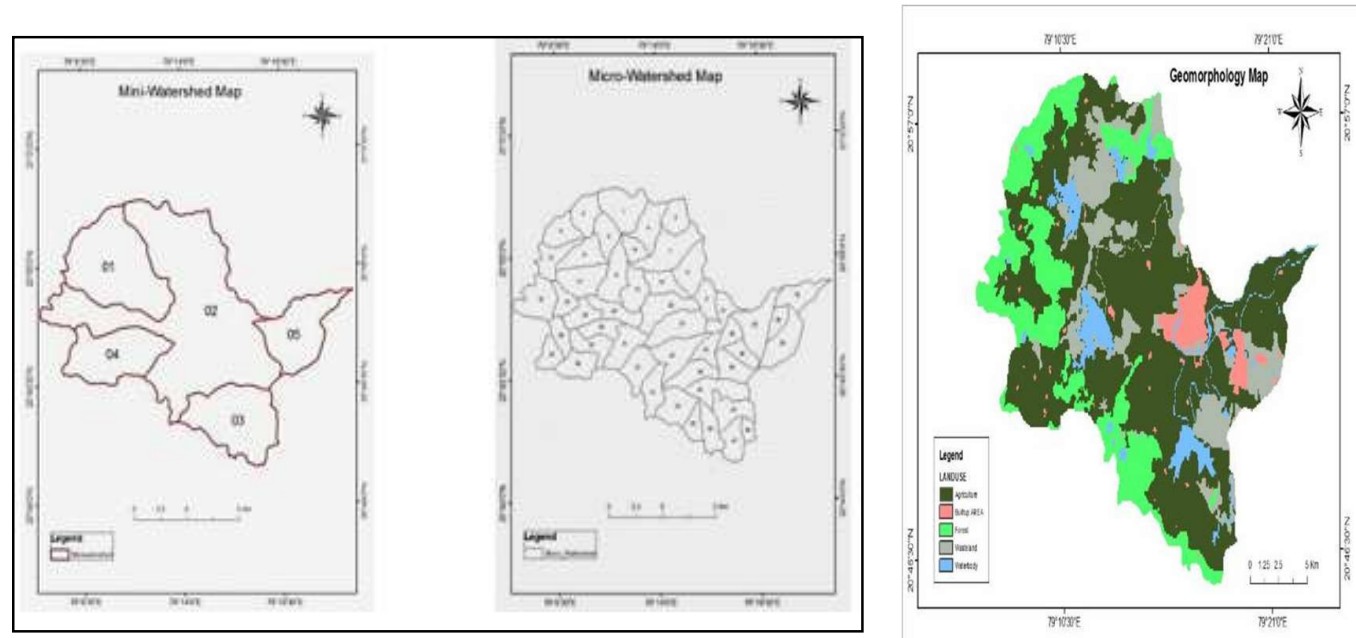

Fig 1: Mini, Micro Watershed Maps and Geomorphological Map

Using the land use land cover map of region the different zones like agriculture, forest, water body, wasteland, built up area were identified. This land use land cover map was superimposed with the microwatershed map. Now the area under agriculture, forest and water body mask was considered for analysis. The watershed comprising of most of the area covered under above zones were selected and further studied for different geological parameters like soil, geomorphology and slope.

\section{Slope}

The precipitous terrain causes rapid runoff and does not store water easily. Slope of any terrain is one of the factors allowing the infiltration of groundwater into subsurface or in other words groundwater recharge. In the gentle slope area, the surface runoff is slow allowing more time for rainwater to percolate, whereas, steep slope area facilitates high runoff allowing less residence time for rainwater to percolate and hence comparatively less infiltration. The slope map of the study area is derived from ASTER DEM $30 \mathrm{~m}$ and slope and area of the study area is given in Table 1. A sample Soil distribution of Agriculture, Forest and Water body mask obtained from ARC-GIS software is shown in Figure 2.

\begin{tabular}{|c|c|c|c|c|c|c|c|}
\hline $\begin{array}{c}\text { Sr. } \\
\text { No. }\end{array}$ & Slope & $\begin{array}{c}\text { Area } \\
\text { Forest } \\
\text { (Sq.Km) }\end{array}$ & $\begin{array}{c}\text { Area } \\
\text { Forest } \\
(\%)\end{array}$ & $\begin{array}{c}\text { Area } \\
\text { Water } \\
\text { body } \\
\text { (Sq.Km) }\end{array}$ & $\begin{array}{c}\text { Area } \\
\text { Water } \\
(\%)\end{array}$ & $\begin{array}{c}\text { Area } \\
\text { Agriculture } \\
\text { (Sq.Km) }\end{array}$ & $\begin{array}{c}\text { Area } \\
\text { Agriculture } \\
(\%)\end{array}$ \\
\hline 1 & $0-3$ & 21.69 & 28.67 & 25.42 & 38.51 & 47.67 & 34.60 \\
\hline 2 & $3-5$ & 21.49 & 28.41 & 18.08 & 27.40 & 41.57 & 30.17 \\
\hline 3 & $5-8$ & 20.41 & 26.98 & 15.18 & 23.00 & 33.58 & 24.37 \\
\hline 4 & $8-14$ & 10.46 & 13.82 & 6.54 & 9.91 & 13.16 & 9.55 \\
\hline 5 & $14-34$ & 1.60 & 2.12 & 0.78 & 1.19 & 1.81 & 1.32 \\
\hline \multicolumn{2}{|c|}{ Total } & $\mathbf{7 5 . 1 5}$ & & $\mathbf{6 6 . 0 6}$ & & $\mathbf{1 3 8 . 0 8}$ & \\
\hline
\end{tabular}

Table 1: Slope and Area of Different Zones 

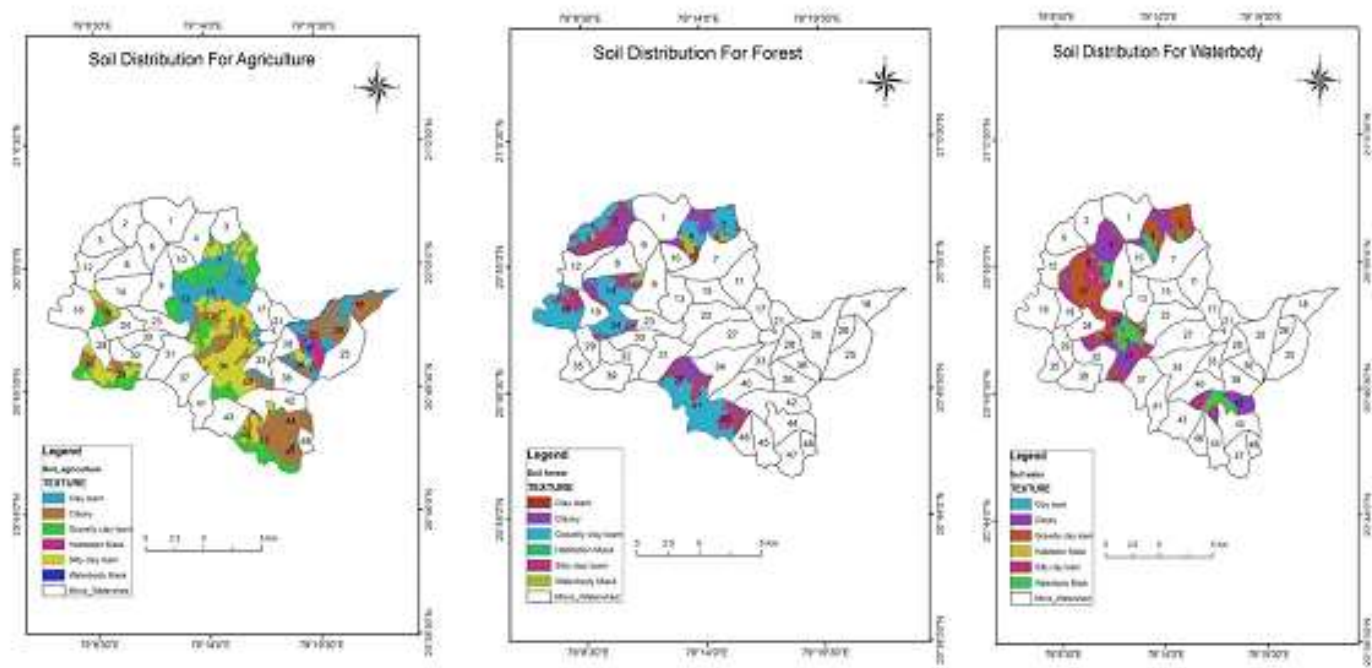

Fig 2: Soil Distribution of Agriculture, Forest and Water Body Mask Obtained From ARC-GIS Software

\section{Methodology}

Artificial Recharge Method for Different Micro-Watershed

After studying the suitability of ground water recharge method for various geomorphological parameters and then studying the various geomorphological parameters of different selected zones of AAM watershed we have suggested following recharge method for improving groundwater within the area

\section{For Agricultural Zone}

Following Table 2 shows best suitable recharge technique for agriculture zone in different micro-watersheds according to their different geomorphological properties discussed and studied above. In overall analysis in agriculture zone most suitable method is ditch and furrow. If existing wells are present over locations the combination of both methods can be used for better results.

\begin{tabular}{|c|l|l|l|}
\hline Sr. No & Recharge Techniques & \multicolumn{1}{|c|}{ Watershed No. } & \multicolumn{1}{c|}{ Justification } \\
\hline 1 & Ditch and Furrow & $\begin{array}{l}46,40,39,35,27,22, \\
19,7\end{array}$ & $\begin{array}{l}\text { As these watersheds contains silty } \\
\text { layey and clayey loam soil and } \\
\text { nearly levelled slope. }\end{array}$ \\
\hline 2 & Recharge well & $\begin{array}{l}47,45,36,26,18,15,13,1 \\
1,34,20\end{array}$ & $\begin{array}{l}\text { These watershed contains clayey } \\
\text { soil and flat topography }\end{array}$ \\
\hline 3 & Combination of both & All above watersheds & $\begin{array}{l}\text { The excess of surface water from } \\
\text { Ditch and Furrow is transferred to } \\
\text { recharge the existing wells available } \\
\text { within the } \\
\text { zone }\end{array}$ \\
\hline
\end{tabular}

For Forest Zone

Table 2: Suitable Techniques for Agricultural Zone

Following Table 3 shows suitable recharge techniques for forest zone in different micro- watersheds in overall analysis percolation tank and recharge pits are most suitable methods that can be applied in forest zone.

\begin{tabular}{|c|c|c|l|}
\hline Sr. No & Recharge Techniques & Watershed No. & \multicolumn{1}{|c|}{ Justification } \\
\hline 1 & Percolation tank & $5,2,14,24$ & $\begin{array}{l}\text { As the area here nearly flat and soil is } \\
\text { gravelly clay loam so the tanks can be } \\
\text { constructed for storage and infiltration will } \\
\text { be more }\end{array}$ \\
\hline 2 & Ditch and furrow & $3,4,16$ & $\begin{array}{l}\text { This area has gentle sloping with silty clay } \\
\text { loam soil which has lower infiltration rate } \\
\text { so this method can be applied. }\end{array}$ \\
\hline 3 & Recharge pits and shafts & $37,41,43$ & $\begin{array}{l}\text { Here presence of gravelly clay loam soil at } \\
\text { shallower depth make this method most } \\
\text { suitable }\end{array}$ \\
\hline
\end{tabular}

Table 3: Suitable Techniques for Forest Zone 
For Water Body Mask

Following Table 4 shows best suitable method for water body mask for different micro- watersheds. In overall analysis the most suitable method is Nalla bund due to presence of streams of order 1 to 4 .

\begin{tabular}{|c|l|l|l|}
\hline Sr. No & Recharge Techniques & Watershed No. & \multicolumn{1}{c|}{ Justification } \\
\hline 1 & Nalla Bund & $42,30,23,14,8$ & $\begin{array}{l}\text { As the no of streams in the vicinity are } \\
\text { large and we can use those streams for } \\
\text { temporary storage by using Nalla Bund. }\end{array}$ \\
\hline 2 & Recharge well & 31,6 & $\begin{array}{l}\text { As in this area recharge wells are present } \\
\text { which can be used as recharging technique }\end{array}$ \\
\hline 3 & Recharge pits and shafts & 3,4 & $\begin{array}{l}\text { This zones contains clayey soil and nearly } \\
\text { leveled slope which is suitable for } \\
\text { recharge pits and shafts. }\end{array}$ \\
\hline
\end{tabular}

Table 4: Suitable Techniques for Water Body Mask

\section{Result \& Discussion}

\section{Estimation of Available Discharge for Recharge in Various Micro-zones}

For different zones of agriculture, forest and water body of watershed the discharge was calculated in each micro-watershed using Rational Method. This method was originally developed for urban catchments. However, this method is fairly applicable to small agricultural watersheds. The Rational method is based on the assumption that constant intensity of rainfall is uniformly spread over an area. The maximum rate of outflow will occur when the rainfall duration is equal to the time of concentration. The relationship for peak runoff, $Q_{p}$ is then expressed as $Q_{p}=$ C.I.A/3.6

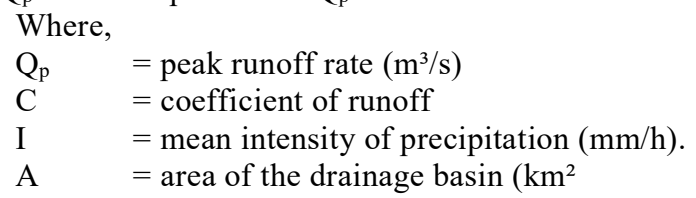

In this study "I", i.e. intensity of rainfall was consider from monthly data of rainfall for Nagpur region. It is considered as 120 hours of rainfall with an average rainfall of $242.52 \mathrm{~mm}$, and then the mean intensity is computed in $\mathrm{mm} / \mathrm{hr}$.

\begin{tabular}{l} 
I $=242.52 / 120=2.02 \mathrm{~mm} / \mathrm{hr}$ \\
\begin{tabular}{|c|l|c|c|c|c|c|c|}
\hline \multirow{2}{*}{ Sr.no } & \multirow{2}{*}{ Months } & \multicolumn{7}{|c|}{ Rainfall (mm) } & \multirow{2}{*}{$\begin{array}{c}\text { Average } \\
\text { Rainfall } \\
\text { (mm) }\end{array}$} \\
\cline { 3 - 7 } & & 2011 & 2012 & 2013 & 2014 & 2015 & 187.18 \\
\hline 1 & June & 119.4 & 67.0 & 390.0 & 92.3 & 277.2 & 329.32 \\
\hline 2 & July & 272.7 & 338.7 & 478.7 & 402.8 & 173.7 & 293.64 \\
\hline 3 & August & 345.7 & 282.9 & 339.3 & 133.0 & 382.3 & 161.64 \\
\hline 4 & September & 185.7 & 273.9 & 101.6 & 125.1 & 136.9 & Total Avg. $\mathbf{2 4 2 . 5 2}$ \\
\hline
\end{tabular} \\
\hline
\end{tabular}

Table 5: Average Monthly Rainfall of Nagpur Region

Typical Calculation of Discharge of a Watershed

A sample calculation of discharge is done using the data of Micro-water shed no. 1.

$$
\mathrm{A}=8.64 \mathrm{Sq} . \mathrm{Km} ; \quad \mathrm{C}=0.4 ; \quad \mathrm{I}=2.02 \mathrm{~mm} / \mathrm{hr} \text {. }
$$

The value of $\mathrm{C}$ is obtained from Table 6 depending on the type of vegetation cover, slope and type of soil. Discharge $\mathrm{Q}=$ C.I.A $/ 3.6=0.4 * 2.02 * 8.64 / 3.6=1.93 \mathrm{~m}^{3} / \mathrm{s}$

\begin{tabular}{|c|c|c|c|c|}
\hline $\begin{array}{c}\text { Type of } \\
\text { Vegetation } \\
\text { cover }\end{array}$ & $\begin{array}{c}\text { Slope Range } \\
(\%)\end{array}$ & \multicolumn{2}{|c|}{ Runoff Coefficient (C) } \\
\cline { 2 - 5 } & $\begin{array}{c}\text { Sandy Loam } \\
\text { Soil }\end{array}$ & $\begin{array}{c}\text { Loam / Loam } \\
\text { Clay Soil }\end{array}$ & Stiff Clay Soil \\
\hline \multirow{2}{*}{$\begin{array}{l}\text { Woodland } \\
\text { and forests }\end{array}$} & $0-5$ & 0.1 & 0.3 & 0.4 \\
\cline { 2 - 5 } & $5-10$ & 0.25 & 0.35 & 0.5 \\
\hline \multirow{3}{*}{ Grassland } & $10-30$ & 0.3 & 0.5 & 0.6 \\
\cline { 2 - 5 } & $0-5$ & 0.1 & 0.3 & 0.4 \\
\cline { 2 - 5 } & $5-10$ & 0.16 & 0.36 & 0.65 \\
\hline \multirow{2}{*}{$\begin{array}{c}\text { Agricultural } \\
\text { land }\end{array}$} & $0-30$ & 0.22 & 0.42 & 0.6 \\
\cline { 2 - 5 } & $5-10$ & 0.3 & 0.5 & 0.7 \\
\cline { 2 - 5 } & $10-30$ & 0.4 & 0.72 & 0.82 \\
\hline
\end{tabular}

Table 6: Values of Runoff Coefficient Factor (C) for Different Soil Conditions in India 
The discharges of various zones i.e., Agriculture, Forest and Water body Mask are computed and shown in the Table 7, Table 8 and Table 9 respectively.

Discharge of Agriculture Zone

The discharge of different micro-watersheds of agriculture zone was computed and given in the Table 7 . The total computed discharge of agriculture zone was $38.58 \mathrm{~m}^{3} / \mathrm{s}$.

\begin{tabular}{|c|c|c|c|c|}
\hline Sr. No. & $\begin{array}{c}\text { Micro- watershed } \\
\text { No. }\end{array}$ & $\begin{array}{c}\text { Runoff coefficient } \\
(\mathbf{C})\end{array}$ & $\begin{array}{c}\text { Area (Sq. } \\
\text { Km) }\end{array}$ & Discharge (m $\left.\mathbf{m}^{\mathbf{3}} \mathbf{s}\right)$ \\
\hline 1 & 11 & 0.4 & 8.65 & 1.94 \\
\hline 2 & 13 & 0.4 & 7.21 & 1.618 \\
\hline 3 & 15 & 0.5 & 5.83 & 1.635 \\
\hline 4 & 18 & 0.55 & 7.03 & 2.169 \\
\hline 5 & 19 & 0.5 & 4.26 & 1.195 \\
\hline 6 & 20 & 0.55 & 11.59 & 3.251 \\
\hline 7 & 22 & 0.5 & 9.85 & 2.763 \\
\hline 8 & 26 & 0.55 & 3.46 & 1.067 \\
\hline 9 & 27 & 0.5 & 11.09 & 3.11 \\
\hline 10 & 34 & 0.5 & 10.4 & 2.917 \\
\hline 11 & 35 & 0.4 & 4.46 & 1 \\
\hline 12 & 36 & 0.5 & 4.01 & 1.125 \\
\hline 13 & 39 & 0.5 & 7 & 1.963 \\
\hline 14 & 40 & 0.5 & 6.91 & 1.938 \\
\hline 15 & 44 & 0.6 & 7.36 & 2.477 \\
\hline 16 & 45 & 0.5 & 6.01 & 1.686 \\
\hline 17 & 46 & 0.5 & 3.78 & 1.06 \\
\hline 18 & 47 & 0.6 & 6.1 & 2.05 \\
\hline 19 & 7 & 0.5 & 12.92 & 3.625 \\
\hline TOTAL & & & $\mathbf{1 3 8 . 0 8}$ & $\mathbf{3 8 . 5 8 9}$ \\
\hline
\end{tabular}

Table 7: Discharge in Agriculture Zone

Discharge of Forest Zone

The discharge of different micro-watersheds of Forest zone was computed and given in the Table 8 . The total computed discharge of Forest zone was $8.1776 \mathrm{~m}^{3} / \mathrm{s}$.

\begin{tabular}{|c|c|c|c|c|}
\hline Sr.no & $\begin{array}{c}\text { Micro- watershed } \\
\text { no. }\end{array}$ & $\begin{array}{l}\text { Runoff coefficient } \\
\text { (C) }\end{array}$ & $\begin{array}{c}\text { Area } \\
(\mathrm{Sq} \cdot \mathbf{K m})\end{array}$ & $\begin{array}{c}\text { Discharge } \\
\left(\mathrm{m}^{3} / \mathbf{s}\right)\end{array}$ \\
\hline 1 & 2 & 0.3 & 7.05 & 1.186 \\
\hline 2 & 3 & 0.1 & 5.91 & 0.3316 \\
\hline 3 & 4 & 0.25 & 8.04 & 1.127 \\
\hline 4 & 5 & 0.3 & 6.81 & 1.146 \\
\hline 5 & 14 & 0.1 & 9.65 & 0.541 \\
\hline 6 & 16 & 0.2 & 10.07 & 1.13 \\
\hline 7 & 24 & 0.1 & 5.45 & 0.305 \\
\hline 8 & 37 & 0.25 & 7.83 & 1.098 \\
\hline 9 & 41 & 0.1 & 6.52 & 0.365 \\
\hline 10 & 43 & 0.2 & 8.47 & 0.948 \\
\hline TOTAL & & & 75.15 & 8.1776 \\
\hline
\end{tabular}

Table 8: Discharge in Forest Zone

Discharge of Water Body Mask

The discharge of different micro-watersheds of Water body mask zone was computed and given in the Table 9. The total computed discharge of Water body mask zone was $11.3388 \mathrm{~m}^{3} / \mathrm{s}$. 


\begin{tabular}{|c|c|c|c|c|}
\hline Sr.no & $\begin{array}{c}\text { Micro- watershed } \\
\text { no. }\end{array}$ & $\begin{array}{c}\text { Runoff coefficient } \\
\text { (C) }\end{array}$ & $\begin{array}{c}\text { Area } \\
(\mathbf{S q . K m})\end{array}$ & $\begin{array}{c}\text { Discharge } \\
\left(\mathbf{m}^{\mathbf{3}} / \mathbf{s}\right)\end{array}$ \\
\hline 1 & 3 & 0.2 & 5.91 & 0.66 \\
\hline 2 & 4 & 0.2 & 8.04 & 0.902 \\
\hline 3 & 6 & 0.45 & 5.99 & 1.512 \\
\hline 4 & 8 & 0.4 & 7.74 & 1.737 \\
\hline 5 & 14 & 0.2 & 9.65 & 1.082 \\
\hline 6 & 23 & 0.2 & 6.43 & 0.721 \\
\hline 7 & 30 & 0.3 & 4.95 & 0.833 \\
\hline 8 & 31 & 0.4 & 8.34 & 1.8718 \\
\hline 9 & 42 & 0.4 & 9.02 & 2.02 \\
\hline TOTAL & & & $\mathbf{6 6 . 0 7}$ & $\mathbf{1 1 . 3 3 8 8}$ \\
\hline
\end{tabular}

Table 9: Discharge in Water Body Mask

The total discharge available in Agriculture zone, Forest zone and Water body mask $(38.589+8.1776+11.3388)$ is $58.10 \mathrm{~m}^{3} / \mathrm{s}$. Therefore, the quantity of water through rainfall is $58.1 * 3600 * 120=25099200 \mathrm{~m}^{3}$.

The following are the losses through which the actual quantity of water for augmentation is reduced. It is assumed that the evaporation loss is $10 \%$, evapo-transpiration loss is $10 \%$, infiltration loss is $10 \%$ and other losses are $10 \%$. The total loss of discharge is $(58.1 * 40 / 100)=23.24 \mathrm{~m}^{3} / \mathrm{s}$. The quantity of water lost due to above losses is $23.24 * 3600 * 120=10039680 \mathrm{~m}^{3}$.

Therefore, the available discharge for artificial recharge would be $(58.1-23.24)=34.86 \mathrm{~m} 3 / \mathrm{s}$. The quantity of water available for artificial recharge is $(25099200-10039680)=15059520 \mathrm{~m}^{3}$.

\section{Conclusions}

- From the ARCGIS software the areas obtained under different zones, Agriculture zone, Forest zone and Water body mask zone are respectively $138 \mathrm{~km}^{2}, 75.15 \mathrm{~km}^{2}$ and $64.21 \mathrm{~km}^{2}$. Seventy percent area of Agriculture and Forest zones are covered by gravel, clayey, silty clay loam type of soil and thirty percent area is covered by clayey soil. Under Water body mask zone fifty percent area is covered by gravelly clay loam, twenty percent of silty clay loam soil and thirty percent is covered clayey soil.

- 70 to $80 \%$ under all the zones has gentle slope less than $5 \%$. This is very favourable for ground water recharge.

- The total computed discharge in all the zones was $58.1 \mathrm{~m}^{3} / \mathrm{s}$ out of which $38.58 \mathrm{~m}^{3} / \mathrm{s}$ is from agricultural zone, $8.17 \mathrm{~m}^{3} / \mathrm{s}$ from forest zone and $11.38 \mathrm{~m}^{3} / \mathrm{s}$ from water body mask. The total losses in the discharge due to evaporation, evapotranspiration, infiltration and other losses is $23.24 \mathrm{~m}^{3} / \mathrm{s}$. The total quantity of water due to rainfall is $25099200 \mathrm{~m}^{3}$ and total quantity of water due to losses is $10039680 \mathrm{~m}^{3}$.

- The available discharge for ground water recharge was found out to be $34.8 \mathrm{~m}^{3} / \mathrm{s}$ and total quantity of water available for ground water recharge is $15059520 \mathrm{~m}^{3}$.

\section{References}

1. Balachandar D., Alaguraja P., Sundaraj P., Ruthar velmurthy K. and Kumaraswamy K.,2010, Application of Remote Sensing and GIS for Artificial Recharge Zone in Sivaganga District, Tamilnadu, India, International Journal of Geomatics and Geosciences, 1(1), pp 84-97.

2. Binay Kumar and Uday Kumar, 2011, Groundwater recharge zonation mapping and modelling using Geomatics techniques, International Journal of Environmental Sciences, 1(7), pp 1670-1681.

3. Brema J. and Prince Arulraj G., 2012, Identification of sites suitable for artificial recharging and groundwater flow modeling in Noyyal river basin, Tamilnadu, India. International Journal of Sustainable Development, 3(8), pp 45-58

4. Central ground water board (cgwb) (http://cgwb.gov.in/District_Profile/Maharashtra/Nagpur.pdf)

5. Chaudhary B. S., Manoj Kumar, Roy A. K. and Ruhal D. S., 1996, Applications of remote sensing and geographic information systems in groundwater investigations in Soha block, Gurgaon district, Haryana (India), International Archives of Photogrammetry and Remote Sensing, 31(B6), pp 18-23.

6. H.D. Bhave, Y.B. Katpatal and A.M. Pophare Identification of ground water recharge potential zone for watershed using GIS and Remote Sensing (IJARET), Volume 10, Issue 1, Jan-Feb 2019, pp. 121-135.

7. H.D. Bhave, Y.B. Katpatal and A.M. Pophare Morphometric analysis of drainage basin of AAM river watershed by using Geoinformatics (JETIR), Volume 6, Issue 4, April 2019

8.Javed Akram and Mushtaq Hussain Wani, 2009, Delineation of groundwater potential zones in Kaknud Watershed, Eastern Rajasthan, Using Remote Sensing and GIS Techniques. Journal of Geological Society of India, 73(2), pp 229-236. 
9. Jothiprakash V., Marimuthu G., Muralidharan R. and Senthil kumar N, 2003, Delineation of potential zones for artificial recharge using GIS. J. of Indian Society of Remote Sensing, 31(1), pp 37-46.

10. Krishnamurthy , J. , \& Venkatesesan, K.N., An approach to demarcate ground water potential maps through remote Sensing and GIS. International Journal of Remote Sensing 7(1996), 1867-1884

11. Mishra Rajat C., Chandrasekhar Biju and Naik Ranjit singh D, 2010, Remote Sensing and GIS for Groundwater Mapping and Identification of Artificial Recharge Sites. Geo-Shanghai International conference, pp216-223.

12. Nepal C Mondal et al. (2011).,Application of remote sensing and GIS for ground water recharge in shivaganga district, Tamilnadu, India.

13. Subagunasekar Met,al 2012 GIS for assessment of ground water recharge potential zone in kakrunkolam block, Thoothukudi district,Tamilnadu, 